\title{
The level of Financial Literacy in Pakistan
}

\author{
Shama Ghaffar * \\ Saqib Sharif ${ }^{\dagger}$
}

\begin{abstract}
This study examines the level of financial literacy in Pakistan. Financial literacy (or financial knowledge) is characteristically an input to assess the requirement for financial education and explain changes in financial outcomes. The study reveals that the individuals, who have the more financial knowledge, usually save more. It is inevitable for investors and the general public that they possess sufficient knowledge and awareness about how financial institutions and markets work; types of risks and expected return, that subsequently is fruitful for the growth of the economy. The results show that 1) middle-aged and older people are careful in spending their money; 2) male respondents usually have better saving habits; 3) people with higher qualification and bigger family size advises their peers about managing the finances; and 4) respondents earning high salaries agree that financial literacy does help in leading a financially secure life. Further, based on evidence, this paper suggests that it is important for policymakers and financial regulators of Pakistan to increase the financial literacy of the masses in general, and especially the female population, in order to minimize the problem of adverse selection and moral hazard.
\end{abstract}

Keywords: Financial literacy, savings rate, Pakistan, personal financial management, household choice

\section{Introduction}

According to Lusardi and Mitchell (2014), financial inclusion emphasizes on the proper development efforts that are undertaken globally and it focuses on the access to finance and financial literacy. Financial literacy is defined as the awareness and the knowledge of the public that is related with the financial services, management of the financial resources and the different concepts that are considered to be very important for the awareness of the general public so that they might get the information related to the different financial terms such as the interest rates, inflation etc. According to Miller, Godfrey, Levesque, and Stark (2009), financial literacy combines the investors' and the consumers' understanding related to the different products and the concepts and the ability to take the effective decisions when it is related to the different financial concepts. It makes the people familiar with the different financial terms. At the macro level, individual savings benefit the whole nation. Savings provide governments with public spending on development projects and financial intermediaries channelize those savings to fuel business investments undertaken by companies. Subsequently, investments by companies brings higher productivity and efficiency that positively impact economic progress. What is more interesting; higher savings also hedge countries against economic downturns and financial crises.

It is well documented that those who study finance, usually save money and make appropriate decision towards investing their surplus funds (Gale, Harris, \& Levine, 2012). In the wake of financial markets integration across the globe, it is becoming important for the investors to be more aware, competent and knowledgeable in monitoring and managing their finances. This becomes necessary due to the complicated characteristics of financial products and services being offered to the general public, which requires informed decisions (Hastings, Madrian, \& Skimmyhorn, 2012).

\footnotetext{
*PhD Scholar, Department of Education, Iqra University, Karachi, Pakistan.

Email: shiza_leo1@hotmail.com

$\dagger$ Department of Economics and Finance, Institute of Business Administration, Karachi, Pakistan.

Email: ssharif@iba.edu.pk
} 
Increasing financial literacy and capability promotes efficient personal financial outcomes, thus, enables better management of life events, such as, higher education, illness, housing, marriage and / or retirement planning. This research is mainly related with the financial literacy among the individuals of Pakistan, since it is important that Pakistani's must have the awareness related to the different important financial concepts.

Through survey data on financial literacy questionnaires from 300 respondents of Karachi, we find that as people grow in their age, they become more careful in spending their earnings. This can be attributed to family size / liabilities and old-age insecurities in developing countries like Pakistan, which does not provide social security to its citizens. Secondly, male members in Pakistani society have the habit of savings. This result is consistent with Yu, Wu, Chan, and Chou (2015) who find gender differences in financial knowledge and analytical abilities among Hong Kong workers. Hence, policy makers should devise such programs that specifically focus on women financial education. Thirdly, persons with higher qualification and large family size (as well as widow / divorced) do advise their peers, friends, and relatives about better utilization of surplus funds. Lastly, respondents with higher income bracket do agree that better knowledge of financial institutions and markets facilitate people to live a financially secure life. Moreover, this paper points to the fact that inherent characteristics developed in childhood and prevailing external environment does play a major role in the decision to save / invest. However, Brockman and Michayluk (2015) suggest that policy interventions to enhance financial knowledge do not seem to impact financial behaviour and savings rates, that might be related to intrinsic characteristics.

Cole, Sampson, and Zia (2011) present convincing evidence that financial literacy is an integral predictor of financial behaviour in developing economies. Hence policy-makers and financial markets are encouraged to promote financial literacy as a means of expanding the depth and breadth of the financial system. Pakistan's financial institutions and markets seem to be facing the same issues due to lack of financial knowledge. Therefore, this study is being conducted to determine the level of literacy of the people of Pakistan related to the finance. Besides, we want to examine how the level of financial literacy, based on different characteristics, affects the financial behaviour of an individual. This paper constitutes proper discussion regarding financial literacy and its importance, which will help the policy makers and individuals who want to get some insight regarding the benefits of having financial knowledge and its impact on financial outcomes within the economy.

The rest of the paper is organized as follows: Section 2 summarizes the aims and objectives of this study; Section 3 focuses on the scope of the study; Section 4 reviews the literature; Section 5 talks about the data \& methodology; Section 6 discusses the results and Section 7 concludes this paper along with implications of research.

\section{Literature Review}

Lusardi and Mitchell (2007) suggest that financial literacy is needed to develop the measures related to the financial competence; to have more knowledge related to the financial matters. Literate people usually participate more in the transactions related to financial matters. Authors have found that the lack of financial acumen is common among the particular groups, like the elders, women and those who are less educated. Another study conducted by Lusardi and Mitchell (2007) on OECD countries have examined the financial literacy component among different countries and have indicated that the degree of financial literacy varies in the different developed countries in which Australia, Japan and the other European countries are taken. Alternative findings are presented by Christelis, Jappelli, and Padula (2010) that the respondents belonging to Europe got the low scores in the financial market participation due to low financial literacy index.

Financial literacy can be explained as the procedure through which individuals manage their finances in terms of savings, investing, budgeting and insurance covering (Boyland \& Warren, 2013). 
Financial literacy is decided by the needs of a person, experience, and expertise, and may have a constructive effect on the personal involvement of customers in the services offered by the financial system. Further, it is the personal capability to make informed decisions about the management and employment of funds (Lusardi \& Scheresberg, 2013).

Additionally, researchers argued that being assured and well-informed in the domains of spending, budgeting and savings are the most important elements of financial literacy. The level of financial knowledge should reflect on the quality of individuals' life (Boyland \& Warren, 2013). The financial literacy is viewed as an answer to the financial complications that individuals and households have to face (Huston, 2010).

It is also identified that financially literate individuals will have an idea as to how they control their financial flow, comprehend how the financial institutions are functioning and have a wide range of logical and systematic skills (Landerretche \& Martínez, 2013). Moreover, financial awareness identifies how individuals need to tackle their financial issues and how to be more responsible financially. In some studies, financial literacy has been defined as the knowledge and comprehension of the fundamental concepts of finance and the capacity to apply them to manage and plan the funds in the most effective and efficient manner (Taft, Hosein, Mehrizi, \& Roshan, 2013).

Many surveys have been conducted to gauge the level of financial literacy. Findings of those surveys demonstrate that individuals with low education level have low knowledge regarding financial management, which consequently impact their financial decision making (Van Rooij, Lusardi, \& Alessie, 2011). Prior evidence also identifies that respondents were unable to plan appropriately for their future and retirement needs. Additionally, they have the inappropriate behavior of borrowing and have a low contribution in stock market investment. This is all because of inadequate knowledge of fundamental concepts of finance (Mandell \& Klein, 2009).

According to Sarma and Pais (2010), cross-country comparison related to the financial inclusion found that there are the differences in the income of the people and due to this difference it plays an important role when it comes to the financial inclusion among the different countries. Moreover, focusing on the adult literacy, the rural population and the unemployment level have not been taken into account, when explaining the differences in the financial inclusion while controlling for the income level.

Zarook, Rahman, and Khanam (2013), have discussed that as the result of the microfinance focus on the financial inclusion; there are different studies that have explored the relationship between the Small and Medium Enterprises (SMEs) and the accessibility to the finance. The analysis of the accessibility at the household level to the financial resources is generally limited to the description of the different statistics as the researchers have aimed to know about the landscape related to the formal and informal financial services that are used by the different people so that their motivations related to the use of the different financial services can be easily understood.

Ellis, Lemma, and Rud (2010) conducted survey in the OECD countries related to the financial literacy and the behaviour. The study focussed at the income, education and the age, and those factors were considered significant determinants to the financial literacy across the 14 countries. However, Gender was not the important factor among the 6 countries when financial literacy was considered.

Ali, Khalid, and Khalid (2012) suggest that Pakistan's large number of households falls under the bottom quartile of the income distribution. Hence it is important to have the place for imparting the financial knowledge while dealing with the different financial matters. Moreover the major element for educating the ultra-poor should include the education related to the use of the different technologies that is part of the financial services for instance the ATMs, mobile banking, internet banking, debit cards, etc. The Benazir Income Support Program (BISP) encourages the beneficiaries to communicate with the formal banking sector by using the different services.

Meier and Sprenger (2013) have explained that the different economists and policymakers have 
argued that financial literacy is the main element when it is related to the financial improvement. But still the problem is despite the importance many individuals still do not have the required knowledge about the financial terms and matters and are seen to be illiterate. In their work they have presented the different results by conducting a field study in which the different decisions of the individuals are considered to determine about the financial literacy. Contrary to the broad evidence, they find that the people who are more financially literate are seen to be attaining less financial benefits than those who are financially less literate.

Fernandes, Lynch, and Netemeyer (2014) conducted the meta-analysis related to the relationship of the financial education and the financial literacy associated with the financial behaviours. Three experimental studies were conducted and it was found that the fractional effects of the financial literacy vanished when one controls for the psychological traits. The reduced role for the financial education is due to the particular behaviours of the people that might affect the policies of the policy makers on the financial education.

Today, easier access to the credit cards, lower transaction costs, free flow of capital in many financial markets and the advancement in technology through which financial services are allocated / offered has certainly left many consumers / investors with the perplex selection about investing their surplus funds and where to invest (Drexler, Fischer, \& Schoar, 2014). Moreover, the literature suggests that there is a sturdy association between the household welfare and the financial knowledge. Studies show that the households having a low degree of financial literacy tend not to make a plan for their future or retirement, own lower levels of assets, and often borrow at a higher rate of interest (Gale et al., 2012).

Additionally, these findings have influenced many policy makers in both developed and developing economies to augment their efforts in improving financial literacy that can improve the savings rate and facilitate the participation of households in the financial markets, which subsequently enhances the efficiency of businesses and decreases the level of poverty (Lusardi \& Mitchell, 2014). Improving and augmenting the financial capabilities and more importantly, literacy endorses better financial decisions. Therefore, better management and planning is observed in the various stages of life, for instance, illness, retirement, education, wedding or house purchase (Mandell \& Klein, 2009).

At the macroeconomic level, savings of individuals benefits the whole nation and promotes their well-being as well (Lusardi \& Mitchell, 2014). Savings has a constructive impact on the country's economy in general as funds that are allocated to the financial assets are then transported via intermediaries to fund the investments by businesses. Those investments by the organizations ultimately contribute towards the economic development and productivity. In addition, higher savings rate may provide a cushion to the countries against the financial crisis and economic recession (Meier \& Sprenger, 2013).

One of the ways to increase the national savings rate is by educating the people about the benefits of personal savings (Meier \& Sprenger, 2013). This can be attained by launching the programs on financial education and to increase the financial literacy of the individuals, i.e., to facilitate them to prepare the financial plans for their future, and select the more suitable financial tools that will aid them to attain their financial goals and objectives. Brockman and Michayluk (2015) also document that Australians with low levels of financial literacy have lower savings rate. Through individual surveys, they also observed noted differences between financial literacy and savings rate across income levels \& age groups; and between genders. Since, one of the objectives of this paper is to investigate the relationship of financial literacy across income, gender, age, family size, etc., it is hypothesized that greater degree of financial literacy entails that people who have better knowledge of their economic and/or financial circumstances are capable of planning their future well, therefore make more informed financial decisions (Boisclair, Lusardi, \& Michaud, 2014). 


\section{Data and Methodology}

The survey instrument was prepared using 10 financial literacy questions as well as information about demographics, such as, gender, age, qualification, income level, occupation, and family size. For conducting this research; quantitative methods were used in which the primary data was collected using survey questionnaires. The advantage of using primary data is that it is not outdated and not previously used. The survey questionnaire was based on 10 questions that were related to the financial literacy sent to 300 citizens belonging to Karachi. The sample was consisted of both, males and females and the questionnaire was based on the rating scales in which the respondents were provided with the range of 1 to 5 to select from. It was ensured that the questions would be formulated in simple and easy language so that the respondents would not feel any difficulty in responding to these questions. Moreover, the questionnaire has not been adapted from any source. All the questions are developed by authors after going through a series of deliberations with finance professionals; that is, industry and academic experts. Lastly, some idea has been extracted from extant literature on financial literacy to finalize the questions. The format of the questionnaire is provided in Appendix-1.

\section{Results and Discussion}

Table 1

Sample Characteristics of 300 Respondents

Panel A: Distribution of respondents across Gender

\begin{tabular}{ll}
\hline Female & $\mathrm{n}=130(43.34 \%)$ \\
Male & $\mathrm{n}=170(56.66 \%)$
\end{tabular}

Panel B: Distribution of respondents across Age

$18-31 \quad \mathrm{n}=74(24.67 \%)$

$32-45 \quad \mathrm{n}=111(37.00 \%)$

46-59 $\mathrm{n}=53(17.67 \%)$

60 and above $\quad \mathrm{n}=62(20.66 \%)$

Panel C: Distribution of respondents across Qualification

High School n=29 (9.67\%)

College $\quad \mathrm{n}=102(34.00 \%)$

Undergraduate $\quad n=84(28.00 \%)$

Postgraduate $\quad \mathrm{n}=85(28.33 \%)$

Panel D: Distribution of respondents across Occupation

Self-employed n=89(29.67\%)

Salaried $\quad n=143(47.66 \%)$

Combination $\quad \mathrm{n}=68(22.67 \%)$

Panel E: Distribution of respondents across Family

Single $n=75(25.00 \%)$

Married $\quad \mathrm{n}=117(39.00 \%)$

Married with Children $\quad \mathrm{n}=83(27.67 \%)$

Divorcee / Widow n=25 (8.33\%)

Panel F: Distribution of respondents across Household Income

25,000 and below $\mathrm{n}=35(11.66 \%)$

$25001-49000 \quad \mathrm{n}=87(29.00 \%)$

$49,001-74,000 \quad \mathrm{n}=59(19.67 \%)$

$74,001-99,000 \quad \mathrm{n}=61(20.33 \%)$

99,001 and above $\quad \mathrm{n}=58(19.34 \%)$

Panel G: Summary Statistics of the Demographics

\begin{tabular}{lccccc}
\hline Demographic Variable & $\mathrm{N}$ & Minimum & Maximum & Mean & Std. Dev. \\
\hline Gender & 300 & 1 & 2 & 1.43 & 0.50 \\
Age & 300 & 1 & 4 & 2.34 & 1.07 \\
Qualification & 300 & 1 & 4 & 2.75 & 0.98 \\
Occupation & 300 & 1 & 4 & 1.93 & 0.73 \\
Family & 300 & 1 & 5 & 2.20 & 0.93 \\
Monthly Income & 300 & 1 & 5 & 3.08 & 1.32 \\
Valid N (list-wise) & 300 & & & &
\end{tabular}


Table 1 presents the sample characteristics of 300 respondents. Panel A depicts that out of 300 respondents, 130 are female $(43.34 \%)$ and 170 are male $(56.66 \%)$ respondents. Panel B shows age distribution of respondents. Around $25 \%$ of respondents fall under 18 to 31 years; $37 \%$ are 32 to 45-year-old; $18 \%$ are 46 to 59 -year-old, and $21 \%$ of the respondents are 60 years and above. Panel $\mathrm{C}$ shows qualification of respondents: around $10 \%$ have passed high-school, $34 \%$ completed their college, $28 \%$ are undergraduates and roughly $28 \%$ have a postgraduate degrees. Moreover, Panel D presents occupation of respondents: $30 \%$ are self-employed, $48 \%$ are salaried individuals and $23 \%$ respondents are doing a job and have their own businesses as well (i.e., combination). Panel E demonstrates family attributes of respondents, $25 \%$ are single, $39 \%$ are married, $28 \%$ of the individuals are married, having children, and $8 \%$ of the individuals are divorced / widow. Lastly, Panel F depicts household income of respondents: $12 \%$ have an incomes of less than Rs. 25,000; $29 \%$ have income in the bracket of Rs. 25,001 - 49,000; $20 \%$ have a monthly income of Rs. 49,00174,000; $20 \%$ falls under Rs. 74,001 - 99,000; and 19\% have a household income of Rs. 99,001 and above.

After this the readers would need to know the level of financial literacy of respondents. The descriptive statistics of financial literacy items are given in Table 2.

Table 2 reveals respondents' overall agreement of the targeted financial awareness predictors. The mean scores of predictors range from 2.72 to 2.97 showing overall agreement throughout. The respondents are of the view that they lack prudence while spending money, and saving from monthly income is not on their agenda. Similarly, the majority of the respondents do not have any monthly budget of spending and do not offer any advice to their friends and relatives about finances, as their own financial knowledge is quite low. On the other hand, the respondents, on average; believe that personal financial literacy do help to lead a secure life and, on average, the respondents have no clue about how the stock market / financial markets work. Likewise, based on questions related to buying of insurance policy, gold, and investing in different assets, the respondents are neutral, that suggests that the degree of financial literacy is very low. Finally; the respondents are indifferent towards saving for retirement. Hence, the univariate results of questionnaires suggest that financial literacy in Pakistan is on the lower side and due to these reasons Pakistan's savings rate is also very low. This subsequently deters the level of investment which is important for economic growth.

Table 2

\begin{tabular}{lccccc} 
Descriptive Statistics of Financial Literacy Items & & & \\
\hline Shortened items & N & Minimum & Maximum & Mean & SD \\
\hline I am careful in spending money & 300 & 1 & 5 & 2.97 & 1.35 \\
I normally save money each month & 300 & 1 & 5 & 2.86 & 1.27 \\
I always use monthly budget & 300 & 1 & 5 & 2.78 & 1.26 \\
I usually give advice about finances to my friends & 300 & 1 & 5 & 2.72 & 1.29 \\
I believe that financial literacy help leads a financially secure life & 300 & 1 & 5 & 2.88 & 1.36 \\
I know how the stock market works & 300 & 1 & 5 & 2.88 & 1.34 \\
I think buying insurance policy is a better investment option & 300 & 1 & 5 & 2.84 & 1.40 \\
I have never thought about saving for retirement & 300 & 1 & 5 & 2.82 & 1.36 \\
I believe investing money in different assets decreases the risk & 300 & 1 & 5 & 2.93 & 1.38 \\
In my opinion purchasing, gold is better than other investments & 300 & 1 & 5 & 2.93 & 1.36 \\
Valid N (listwise) & 300 & & & & \\
\hline
\end{tabular}

Next, we run a multivariate regression on each question as the dependent variable and the demographic characteristics as independent variables. However, before conducting a multivariate regression analysis, it is important to test for the presence of multicollinearity among demographic independent variables. Based on the results, not shown here, we find that independent variables are not correlated with each other. Hence multicollinearity is not an issue and we can safely run Ordinary Least Squares (OLS) regressions.

1) I am careful in spending money:

The regression result for the first question in Table 3 shows significant negative coefficient 
with age at $1 \%$ level. This suggests that as the respondents' age increases, they become more prudent about spending their monthly income / earnings. This also confirms that with passing age the responsibilities of individuals also increase, such as marriage and children, and thus they are typically careful before incurring any expenses.

Table 3

Multiple Regression of Financial Literacy Scores of Pakistani Respondents ( $\mathrm{n}=300)$

\begin{tabular}{lcccc}
\hline & Coefficient & Std. Error & T-stats & P-value \\
\hline Monthly Income & 0.0316 & 0.0589 & 0.54 & 0.592 \\
Family Size & -0.0574 & 0.0843 & -0.68 & 0.496 \\
Occupation & 0.0098 & 0.1076 & 0.09 & 0.928 \\
Qualification & -0.1126 & 0.0805 & -1.40 & 0.163 \\
Age & $-0.2159^{* * *}$ & 0.0731 & -2.95 & 0.003 \\
Gender & -0.1764 & 0.1583 & -1.11 & 0.266 \\
Constant & $4.0453^{* * *}$ & 0.4825 & 8.38 & 0.000 \\
$R$-Square & 0.0404 & & & \\
F-Stat & 2.06 & & & \\
\hline ***, and ${ }^{* * *}$ represents significance at 10\%, 5\%, and 1\% respectively. & & & &
\end{tabular}

\section{2) I normally save money each month:}

The regression result for the second question in Table 4 shows weakly significant negative coefficient with gender at $10 \%$ level. This suggests that male respondents, on average, have better saving habits compared to females. The evidence is consistent with the study by (Yu et al., 2015). Further, many other studies suggest that South Asian Women are not good at managing finances, and this job is to be carried out by male members of the family.

3) I always use monthly budget:

The regression result of the third question have no significant relationship with any of the demographic characteristics. The result, not shown here, concludes that use of monthly budget has, on average, nothing to do with demographic characteristics of respondents.

Table 4

Multiple Regression of Financial Literacy Scores of Pakistani Respondents ( $\mathrm{n}=300)$

\begin{tabular}{lcccc}
\hline & Coefficient & Std. Error & T-stats & $\boldsymbol{P}$-value \\
\hline Monthly Income & -0.0047 & 0.0557 & -0.09 & 0.932 \\
Family Size & -0.0216 & 0.0797 & -0.27 & 0.786 \\
Occupation & $-0.1975^{* *}$ & 0.1017 & -1.94 & 0.053 \\
Qualification & 0.0187 & 0.0761 & 0.25 & 0.806 \\
Age & -0.1068 & 0.0691 & -1.54 & 0.124 \\
Gender & $-0.2530^{*}$ & 0.1496 & -1.69 & 0.092 \\
Constant & $3.8654^{* * *}$ & 0.4561 & 8.48 & 0.000 \\
$R$-Square & 0.0332 & & & \\
F-Stat & 1.67 & & & \\
\hline ***, and ${ }^{* *}$ represents significance at 10\%, 5\%, and 1\% respectively. & & & &
\end{tabular}

\section{4) I usually give advice about finances to my friends:}

The regression result for the fourth question in Table 5 shows significantly positive coefficient with family (or size of family) at $5 \%$ level and weakly significant positive coefficient with qualification. This suggests that married respondents with children and divorced / widow usually advise their peers about managing the finances. Because, in developing country like Pakistan, such kind of people suffer from social and financial insecurities; and hence willing to guide relatives and friends about personal financial management. On the other hand, the positive association of qualification with question four shows that highly qualified people generally are good at advising others on personal financial management. 
Table 5

Multiple Regression of Financial Literacy Scores of Pakistani Respondents $(\mathrm{n}=300)$

\begin{tabular}{lcccc}
\hline & Coefficient & Std. Error & T-stats & P-value \\
\hline Monthly Income & -0.0791 & .05637 & 1.40 & 0.161 \\
Family Size & $0.1791^{* *}$ & .0806992 & 2.22 & 0.027 \\
Occupation & -0.0259 & .1030477 & -0.25 & 0.802 \\
Qualification & $0.1295^{*}$ & .0770289 & 1.68 & 0.094 \\
Age & 0.0060 & .0700108 & 0.09 & 0.932 \\
Gender & -0.1590 & .1515186 & -1.05 & 0.295 \\
Constant & $1.9868^{* * *}$ & .4618921 & 4.30 & 0.000 \\
$R$-Square & 0.0417 & & & \\
F-Stat & 2.12 & & & \\
\hline ***, and ${ }^{* *}$ represents significance at 10\%, 5\%, and 1\% respectively. & & & &
\end{tabular}

5) I believe that personal financial literacy can help lead a financially secure life:

The regression result for the fifth question in Table 6 shows significantly positive coefficient with family income at $10 \%$ level; significantly negative coefficient with family; and significantly negative relationship with age. This suggests that respondents with higher incomes do believe that financial literacy plays a critical role in planning the future. On the other hand, married respondents with children and divorced / widow do have an opposite response, that is difficult to interpret. Lastly, younger people agree with the question about having a financially secure future with better financial awareness.

Table 6

Multiple Regression of Financial Literacy Scores of Pakistani Respondents (n=300)

\begin{tabular}{lcccc}
\hline & Coefficient & Std. Error & T-stats & P-value \\
\hline Monthly Income & $0.1067^{*}$ & 0.0591 & 1.81 & 0.072 \\
Family Size & $-0.2019^{* * *}$ & 0.0846 & -2.39 & 0.018 \\
Occupation & 0.0368 & 0.1080 & 0.34 & 0.733 \\
Qualification & 0.1170 & 0.0807 & 1.45 & 0.148 \\
Age & $-0.1373^{*}$ & 0.0734 & -1.87 & 0.062 \\
Gender & 0.1131 & 0.1588 & 0.71 & 0.477 \\
Constant & $2.7655^{* * *}$ & 0.4840 & 5.71 & 0.000 \\
$R$-Square & 0.0503 & & & \\
F-Stat & 2.59 & & & \\
\hline **, and ${ }^{* *}$ represents significance at 10\%, 5\%, and 1\% respectively. & & & &
\end{tabular}

6) I know how the stock market works:

The regression result of the sixth question have no significant relationship with any of the demographic characteristics. The result, not shown here, concludes that, on average, respondents have very little idea of how financial market / stock exchange works, irrespective of income, qualification, profession etc. The findings of no relationship with financial literacy questions points to the fact that sometimes policy interventions do not alter the financial behaviour of individuals due to inherent characteristics as suggested by (Brockman \& Michayluk, 2015).

7) I think buying insurance policy is better investment option:

The regression result of the seventh question have no significant relationship with any of the demographic characteristics. The result, not shown here, concludes that, on average, respondents have very little idea of how useful is buying an insurance policy, irrespective of income, qualification, profession etc. Further, in Pakistan, the World Bank estimate suggests that population buying Life Insurance Policy is one of the lowest in the region.

8) I have never thought about saving for retirement:

The regression result of the eighth question have no significant relationship with any of the demographic characteristics. The result, not shown here, concludes that, on average, respondents have very little idea of saving for future needs, such as education and marriage of children and / or saving for retirement.

9) I have never thought about saving for retirement: 
The regression result of the ninth question have no significant relationship with any of the demographic characteristics. The result, not shown here, concludes that, on average, respondents have very little or no idea about diversification of money / investments and its impact on minimizing the risk.

10) In my opinion purchasing gold is better investment than government savings schemes:

The regression result of the tenth question have no significant relationship with any of the demographic characteristics. The result, not shown here, concludes that, on average, respondents are indifferent towards either investing in gold and gems or government approved securities.

\section{Conclusion}

Saving is important for the long-run development and economic progress of the nation. In addition, saving acts as a contingency for people and countries within the event of economic downturns and financial crises. Overall, this study has shown that financial literacy is a vital determinant of individual savings. Evidence suggests that if the influential person aims to extend saving amongst households, it ought to increase efforts in promoting financial literacy through basic academic programs relating to financial problems.

Through survey data on financial literacy questions from 300 respondents in Karachi, we find that middle-aged people are prudent in spending their incomes. This can be attributed to family liabilities and old-age insecurities. Secondly, male members of Pakistani society have the habit of saving. This result is consistent with $\mathrm{Yu}$ et al. (2015) who suggest that gender difference in financial literacy could possibly be explained by gender difference in risk tolerance and analytical abilities. Hence, policy makers may think of developing programs that aim towards women financial education. Thirdly, persons with better qualification and bigger family advise their co-workers, friends, and relatives about better investment options. Lastly, respondents with higher income bracket agree that better knowledge of financial infrastructure facilitates people to live a troublefree life.

Moreover, we motivate our paper to map the financial literacy questions / scores with the demographics of respondents. Since, Brockman and Michayluk (2015) suggest that policy interventions to upgrade financial knowledge play negligible role in altering the financial behaviour and savings rates, that might be significantly related to intrinsic characteristics. Our paper also points to the fact that inherent factors developed in childhood and environment factors also play a major role on the financial outcomes, since we find no significant relationship for some of our financial literacy questions with demographic characteristics of respondents.

Effects of demographic factors, however, show that older folks tend to save more. This finding is intuitive as older individual would have saved for an extended time with more and more family responsibilities, hence, accumulated additional funds for savings. This study focused on people living in the biggest metropolis of Pakistan (i.e., Karachi), thus, further analysis ought to be conducted to include other cities and towns of Pakistan.

This study has indicated that the males of Pakistani society are more aware about the different concepts of the finance as they get more exposure to the different financial activities as compared to the females. Also, people with more education have better knowledge about different financial products and services. Females have little knowledge about the use of different finance related technologies such as ATM, Debit card, online banking etc.

Moreover, this study also raises questions for future research, such as, whether having financial skills will increase peoples' involvement in savings / investments? How people go for (or allocate funds for) other saving programs like insurance plans? And what is the association between financial literacy and financial risk tolerance within the context of recent unpredictable and complex financial markets? Since, our paper finds a significant association of demographic variables with few of the 
financial literacy questions.

\section{Implications for research, practice and/or society}

This research emphasized on financial literacy, especially related to Pakistan. This research would be helpful to determine the financial literacy among the people of Pakistan, facilitating the policy makers about the degree of financial acumen and how much policy intervention is required to impart the financial education in order to increase the level. Moreover, it is very important to have a reasonable amount of financial knowledge that would translate into widening of breath and depth of financial system / markets. Individuals with surplus funds and investors can also get some insight from this study to mitigate the risk of information asymmetry. 


\section{References}

Ali, K., Khalid, U., \& Khalid, Z. (2012). Promoting financial inclusion and literacy in Pakistan via G2P payment programs. Pakistan Microfinance Network. Retrieved from http://www .microfinancepakistan.com/dev/assets/articles

Boisclair, D., Lusardi, A., \& Michaud, P. C. (2014). Financial literacy and retirement planning in Canada (Tech. Rep.). Retrieved from http://dx.doi.org/10.3386/w20297

Boyland, J., \& Warren, R. (2013). Assessing the financial literacy of domestic and international college students. Johnson \& Wales University MBA Student Scholarship Paper 18. Retrieved from http://scholarsarchive.jwu.edu/mbastudent/18

Brockman, P., \& Michayluk, D. (2015). How does financial literacy affect the savings decision? SSRN Electronic Journal. Retrieved from http://dx.doi.org/10.2139/ssrn.2667283

Christelis, D., Jappelli, T., \& Padula, M. (2010). Cognitive abilities and portfolio choice. European Economic Review, 54(1), 18-38.

Cole, S., Sampson, T., \& Zia, B. (2011). Prices or knowledge? what drives demand for financial services in emerging markets? The Journal of Finance, 66 (6), 1933-1967.

Drexler, A., Fischer, G., \& Schoar, A. (2014). Keeping it simple: Financial literacy and rules of thumb. American Economic Journal: Applied Economics, 6(2), 1-31.

Ellis, K., Lemma, A., \& Rud, J.-P. (2010). Investigating the impact of access to financial services on household investment (Tech. Rep.). Financial Inclusion in Kenya. Retrieved from http:// dspace.africaportal.org

Fernandes, D., Lynch, J. G., \& Netemeyer, R. G. (2014). Financial literacy, financial education, and downstream financial behaviors. Management Science, 60(8), 1861-1883.

Gale, W. G., Harris, B. H., \& Levine, R. (2012). Raising household saving: Does financial education work. Social Security Bulletin, $72(2), 39-48$.

Hastings, J. S., Madrian, B. C., \& Skimmyhorn, W. L. (2012). Financial literacy, financial education and economic outcomes (Tech. Rep.). National Bureau of Economic Research. Retrieved from http://dx.doi.org/10.3386/w18412

Huston, S. J. (2010). Measuring financial literacy. Journal of Consumer Affairs, 44(2), 296-316.

Landerretche, O. M., \& Martínez, C. (2013). Voluntary savings, financial behavior, and pension finance literacy: evidence from Chile. Journal of Pension Economics and Finance, 12(3), $251-297$.

Lusardi, A., \& Mitchell, O. S. (2007). Baby boomer retirement security: The roles of planning, financial literacy, and housing wealth. Journal of Monetary Economics, 54 (1), 205-224.

Lusardi, A., \& Mitchell, O. S. (2014). The economic importance of financial literacy: Theory and evidence. Journal of Economic Literature, 52(1), 5-44.

Lusardi, A., \& Scheresberg, C. D. B. (2013). Financial literacy and high-cost borrowing in the United States (Tech. Rep.). Retrieved from http://dx.doi.org/10.3386/w18969

Mandell, L., \& Klein, L. S. (2009). The impact of financial literacy education on subsequent financial behavior. Journal of Financial Counseling and Planning, 20(1), 15-24.

Meier, S., \& Sprenger, C. D. (2013). Discounting financial literacy: Time preferences and participation in financial education programs. Journal of Economic Behavior 63 Organization, 95(1), 159-174.

Miller, M., Godfrey, N., Levesque, B., \& Stark, E. (2009). The case for financial literacy in developing countries: promoting access to finance by empowering consumers (Tech. Rep.). World Bank, Washington DC.

Sarma, M., \& Pais, J. (2010). Financial inclusion and development. Journal of International Development, 23(5), 613-628. 
Taft, M. K., Hosein, Z. Z., Mehrizi, S. M. T., \& Roshan, A. (2013). The relation between financial literacy, financial wellbeing and financial concerns. International Journal of Business 6 Management, 8(11), 63-75.

Van Rooij, M., Lusardi, A., \& Alessie, R. (2011). Financial literacy and stock market participation. Journal of Financial Economics, 101(2), 449-472.

Yu, K. M., Wu, A. M., Chan, W. S., \& Chou, K. L. (2015). Gender differences in financial literacy among Hong Kong workers. Educational Gerontology, 41(4), 315-326.

Zarook, T., Rahman, M. M., \& Khanam, R. (2013). The impact of demographic factors on accessing finance in Libya's SMEs. International Journal of Business and Management, 8(14), 55-65. 